\title{
"It Depends:" From Narration Sickness to Wide Awake Action in Music Education
}

\author{
Cara Faith Bernard \\ University of Connecticut \\ Matthew Rotjan \\ Scarsdale Middle School, NY
}

In this article, we query how action is contextualized and used in music education, centering the discussion around problems of calling for change without taking action, what Paulo Freire terms "narration sickness." Narration sickness manifests in social media, conferences, and professional development sessions-where words convey ideas as grand narratives, devoid of context, causing a division between those who present ideas from those who enact them in practice. We describe how music educators may become unintentional slacktivists, "woke" to the need for action, attempting to improve the field with limited (if any) action at all. We invite music educators to counter "wokeness" with what Maxine Greene calls being "wide awake," offering examples of educators who demonstrate change. We seek to expand the definition of action, drawing upon what Freire and Marx term as praxis, seeking actionable approaches in teaching, researching, and learning across age levels, settings, and contexts.

Keywords: narration sickness, praxis, music education, slacktivism, social media, wide awake

\footnotetext{
7 magine sitting in a conference presentation or scrolling through a social media feed, hearing or reading the following comments and conversations:

"We need to educate the 21st century musician. Creativity, collaboration, critical thinking, and communication need to come together in our music classrooms and ensembles."
}

(C) Cara Faith Bernard and Matthew Rotjan. The content of this article is the sole responsibility of the author. The ACT Journal and the Mayday Group are not liable for any legal actions that may arise involving the article's content, including, but not limited to, copyright infringement. 
Q: "How can I do this in my classroom? Do you think if I had the students just learn in smaller groups, your idea of providing autonomy and collaboration would work with my students?”

A: "Well, you know, it's situational; it depends on your situation, so I can't really tell you what to do."

$* * *$

"Music educators need to be more socially just! We need to revisit our curriculum, pedagogy, and overall lens of how we view the work of music education in schools."

"This, y'all. We need to be the changes, because music and teaching are political. So get moving!" \#wakeup \#bethechange

These are quotes that we-a university-level music teacher educator and a K12 teacher-have read or heard from colleagues in many social and professional situations. We have found ourselves in conferences, professional development sessions, and conversations with colleagues and administrators via social media and in person, during which we were charged with making bold changes around issues including social justice, curricular mandates, creativity, and inclusion in music education. Yet, we are often left wondering, "Could I implement this into my classroom?" "Why do I need to make these changes?" and "What actions might I take to make them?"

As presenters in these settings, we have left our own presentations wondering, "Have I done a good job? Have I given a 'takeaway' to the audience?" and "Is what I just spoke about relevant for my audience?" so that they can make changes and take action in their own settings. These competing thoughts challenge those who teach in K-12 settings, research or write philosophical work, or encourage pre- and in-service music teachers to consider their roles as music educators. Does action mean putting words and ideas out into the world, or doing more?

In a setting such as a conference or professional development-or even on social media-when a well-meaning music educator asks the question, "How can I do this?" all too often the presenter or facilitator responds: "It depends on your situation," or "I can only ask you more questions than give answers." Imagine an example that we, the authors, have experienced many times, either as presenters or as audience members: an idea is presented, say, that music educators need to be more culturally relevant in the classroom (Ladson-Billings 2014; Lind and McKoy

Bernard, Cara Faith, and Matthew Rotjan. 2021. "It depends:" From narration sickness to wide awake action in music education. Action, Criticism, and Theory for Music Education 20 (1): 5383. https://doi.org/10.22176/act20.1.53 
2016). A practicing teacher raises their hand and asks, "How do I do this with my 5 th graders?" The presenter provides a bland, "Well it depends, like on the demographic makeup of your school, your class size, and even what your colleagues do," or "you need to be responsive" and moves on without allowing for greater conversation to consider context or further examples to think through the idea.

While one's actions should depend on context, and may change depending on setting, situation, and students, these responses leave us (the authors) frustrated. While the presenter or social media poster might not have background knowledge of setting and context to provide a specific answer, we have noticed that instead of providing a possible solution or even discussing the question, responding with "it depends on your situation" allows the presenter to field the question or charge without answering it directly. In their role, the presenter or poster earns the audience's attention, transmitting the presentation as one-way information rather than offering consultations or examples to a barrage of individual circumstances (Ravn and Elsborg 2011). The session or post ends with little guidance on how to think through the ideas, with questions left unanswered and open to interpretation; this leaves music educators with the responsibility to interpret into action the words, ideas, and charges within the context of their daily work with students.

To clarify, we are not arguing "as if it were perfectly clear what [for example, culturally relevant pedagogy] means and as if achieving [culturally relevant] practices in music education were simply a matter of making minor technical adjustments to instructional method and content" (Bowman 2007, 2). Nor do we argue that the presenter must have a solid answer to all questions. But such examples beg a deeper inquiry into how action is defined and created. We see and hear the clamoring for support of our practicing K-12 and higher education teacher colleagues who wish for attention, validation, and guidance in making changes for their situations; we write this article with an intentional desire to examine what calling out problems and creating change around them might look like.

When music educators (when we use this term, we encompass K-12 teachers, professors, and researchers) participate in personal conversations, on social media, in professional development, and at conferences, or even through articles, words and dialogue can often be seen-in whatever way-as an action (Class and Miranda 2019, Jenkins 2016). The above scenario and the opening quotes of this paper may connote that music educators at all levels believe they are linking ideas-theory-to practice in actionable ways. This juncture-often referred to as

Bernard, Cara Faith, and Matthew Rotjan. 2021. "It depends:" From narration sickness to wide awake action in music education. Action, Criticism, and Theory for Music Education 20 (1): 5383. https://doi.org/10.22176/act20.1.53 
praxis (Freire 1970, Marx 1846)-is compromised by words alone (Freire 1970, 87-8). Action is a process of follow through, from ideas and words to making change in a specific setting. A tension arises between the specific call for change and the methods used to bring it about, especially if individuals expect a "here'show-you-do-it" approach to implementation (Bowman 2007, 5). The words and dialogue, however, are not actionable unless they address "circumstances that might be characterized as local and concrete rather than global and abstract" (Bowman 2007, 3). Amidst the lack of direction for "how" change might occur, we ask, how might music educators follow through on words, ideas, and charges in actionable ways? How can music educators balance conceptual thinking and responsiveness while also providing relevant models and advice to imagine and enact those ideas for change?

In this article, we query how action is contextualized and used in music education, centering the discussion around problems of calling for change without taking action, what Paulo Freire terms "narration sickness." This sickness manifests in social media, conferences, and professional development sessions, where words conveying vague and redundant messages form a shared grand narrative. We describe the ways in which, through words and ideas divorced from context and change, music educators become unintentional "slacktivists"- "woke" to the need for action, but whose attempts to improve the field rely upon limited (if any) action at all. Further, we invite music educators to counter "wokeness" with being "wide awake" (Greene 1995) in their teaching and offer exemplars of K-12 music educators-including Matt (the co-author)-who demonstrate actionable change through this awakeness. We have engaged with these in-service teachers through observations and collaborations over the last several years. Based on our close professional relationships, we turned to them for conversation and example as we wrestled with ideas and action. We highlight one way in which the academy and school environments may strengthen and inform one another's wide awakeness with ideas that may become actionable, engaging in what Freire and Marx term as praxis. We intentionally embrace this work together, searching for more actionable steps in teaching, researching, and learning across age levels, settings, and contents.

Bernard, Cara Faith, and Matthew Rotjan. 2021. "It depends:" From narration sickness to wide awake action in music education. Action, Criticism, and Theory for Music Education 20 (1): 5383. https://doi.org/10.22176/act20.1.53 


\section{Narration Sickness in Music Education}

Over 50 years ago, Paulo Freire (1970), frustrated with a lack of action in teaching and learning, wrote, "Education is suffering from narration sickness" (71). Narration sickness occurs when a teacher takes on the passive role of narrator-talking at students without consideration or context of who they are; in other words, when teaching occurs without connection between content and student experiences. In the classroom, as the teacher speaks, the "Narration leads the student to memorize mechanically the narrated content. Worse still, it leads them into containers, into receptacles to be filled by a teacher. The more meekly the receptacles permit themselves to be filled, the better they are" (71-2). The students about whom Freire spoke experienced an education where the ideas and cultures of schooling were imparted upon them, rather than controlling their own learning through exploration and experience. Freire referred to narration sickness in terms of the constant use of teachers depositing-or "banking"-information to students (72), reminding readers that words are meaningless when they are not actionable:

When a word is deprived of its dimension of action, reflection automatically suffers as well; and the word is changed into idle chatter, into verbalism, into an alienated and alienating "blah." It becomes an empty word, one which cannot denounce the world, for denunciation is impossible without a commitment to transform, and there is no transformation without action. (87)

For Freire, words untied to action become "blah." They are empty, with no significant action, no transformation. This "blah" is exemplified in the opening quotes of this paper, where music educators argue for change but do not provide actionable approaches for how to achieve it in individual (or any) contexts. Rather, they counter with responses of "it depends." Freire (1970) argued that naming a problem as a call for change-or problem posing (79-80)-is an important step toward making change; yet without action to confront and solve said problem, one's words only add to the "blah" and narration sickness.

Many have written about problem posing and Freire in music education (Abrahams 2005, 2019; Abrahams and John 2019; Allsup 2003; Hess 2017, 2019, Schmidt 2005; Smith, Dines, and Parkinson 2017; Talbot and Williams 2019), citing the importance of reflection and transformative change among students and teachers. We work in similar frameworks as these scholars around problem posing and action, seeking change to further our field. However, we fear that in music

Bernard, Cara Faith, and Matthew Rotjan. 2021. "It depends:" From narration sickness to wide awake action in music education. Action, Criticism, and Theory for Music Education 20 (1): 5383. https://doi.org/10.22176/act20.1.53 
education, words have become "blah," naming problems without attention to context or taking action upon them to make change.

The solution to narration sickness, Freire argued, is praxis (1970). He referred to praxis as action that weaves theory, reflection, and practice seamlessly (126); it is the transformation of ideas through human action or labor upon something. Without praxis, there is a division between action and theory. For praxis to occur, action and idea become codependent on one another, held in tandem and balanced through dialogue and context (Goodson 2009). Action without reflection or thought, without an awareness of context, immobilizes both concepts, one which leaves a void for dialogue and a "nervous" action (xiv) in its place. This nervous action is more of a reactive action (or reaction), one which thrives on action alone; as a result, action loses meaning. Meanwhile, another imbalance, reflection on words and ideas without action, becomes what Freire termed as "babbling." "Dialogic seriousness and surrender to a critical quest," wrote Freire, "must not be confused with babbling. To dialogue is not to babble" (Freire and Araújo 1998, 99).

Freire came to this solution of praxis through a reliance on Karl Marx (1846), who was woefully aware of how society permits or privileges some to think while others are not allowed or encouraged to do so. Marx described a division of labor between those who think and those who do or engage in manual labor:

One part appears as the thinkers of the class (its active, conceptive ideologists, who make the perfecting of the illusion of the class about itself their chief source of livelihood) while the others' attitude to these ideas and illusions is more passive and receptive because they are in reality the active members of this class and have less time to make up illusions and ideas.... (Marx 1846, 173)

In other words, there are those who have the opportunity to think and not enact any labor, and others who must labor to survive. The labor group-the manual workers-is left with the role of having to do the "real work." This structure causes a divide between those who make (or present) the ideas and those who execute them. Some have written that researchers are particularly susceptible to this divide, as they have the concession to impart ideas, leaving practicing teachers to implement them (Giroux 1988, Souto-Manning 2019). When related to education structures, one might interpret that theory "favors certain actors, particularly academics, teachers, and scholars" (Allsup 2003, 160).

Bernard, Cara Faith, and Matthew Rotjan. 2021. "It depends:" From narration sickness to wide awake action in music education. Action, Criticism, and Theory for Music Education 20 (1): 5383. https://doi.org/10.22176/act20.1.53 
In applying Marx's division of labor, we interpret laborers to be the educators, namely, K-12 teachers in school contexts. By this we do not mean that K-12 teachers as laborers are incapable of thinking or crossing the divide; nor do we view scholars solely as thinkers. Praxis, Randall Allsup (2003) claimed, "is not simply the capacity to imagine alternative scenarios, but is instead the slow burning fuse of possibility and action" (157). Rather, when framed through Freire's (1970) narration sickness, the "blah" of narration hides in the division between those educators who theorize, elusive to action and change (126), and the worker-educators who are left to the task of executing ideas in their classrooms, often without guidance or attention to context.

This division is similar to Freire's (1970) argument that the detachment between student and narrator-teacher is problematic. He proposed instead the term "teacher-student with students-teachers" (80), where both roles continuously work with one another, reciprocally (Freire 1970, 83; 1998, 63, 68): "People teach each other, mediated by the world, by the cognizable objects which in banking education are 'owned' by the teacher" (Freire, 1970, 80). In these roles, they pose problems (79) occurring in their world, describe, or "name" them, consider ways to solve them, and then take action to solve them $(83,85)$. We argue that narration sickness in music education often impedes educators from problem posing and solving. Narration sickness currently appears through the theorizing of ideas on social media, in conferences, and professional development sessions, whenever educators (in K-12, higher education, or elsewhere) use the platforms to say, "it depends," naming or posing problems (Freire 1970, 83) without attaching context or action to solve them.

\section{Narration Sickness in Social Media}

Narration sickness in music education is exemplified in the way interactions occur on social media. For many, social media offer several platforms to which music educators may look for ideas about teaching, researching, and learning; they may join groups, affiliate with professional organizations, and engage in conversation through reading, dialogue, audio, and video (Cayari 2021; Shin 2018; Waldron 2013; Waldron, Horsley, and Veblen 2020). In their structure and setting, social media present multiple ways for music educators to engage and participate, ways that create a platform for action and inaction simultaneously.

Bernard, Cara Faith, and Matthew Rotjan. 2021. "It depends:" From narration sickness to wide awake action in music education. Action, Criticism, and Theory for Music Education 20 (1): 5383. https://doi.org/10.22176/act20.1.53 
We have seen posts (and admit to posting ourselves) on social media that call out troublesome issues in education and the need for change. These calls sometimes exist as article links or quotes from a social figure posted on an individual's profile page, captioned, "This" or "Important, read." For example, proclaiming recognition of a problem on social media by posting, "Music education in schools advances oppressive systemic bias" or "Just witnessed true creativity in the classroom!" or "YES!" accompanied by a link to an article (that one would need to read to understand the poster's response) suggests to the audience that the one who posts is naming problems.

We have also seen the babbles of narration sickness on social media when someone responds to a poster's query asking for teaching advice by providing labor-based answers that are tried and true, no-fail practices. These respond to such questions as, "how do I help tune parallel thirds in my 5 th grade chorus?" "How do I accommodate a violinist with three fingers on their left hand?" or "A student who has done steel pan drumming just moved to our district and wants to play in the band. How do I include this student in my ensemble?" Like the "it depends" responses to these types of queries, many of them (but not all), too, lack context, or they have some context but not enough to encourage discussion. A look at the problem in its ethnographic place of the school (K-12 or higher education) with the teacher and students is often absent, as is the context of the conversation of connecting theory and practice.

We identify the above types of exchanges, respectively, as both "blah" and nervous action (Goodson 2009). Captioning something with "This" and then using or sharing (e.g., sharing a post on Facebook or "retweeting" on Twitter) someone else's words, leaves the reader to guess what the poster's actual thoughts are (Boyd, Golder, and Lotan 2010) or how to work through an idea in terms of their own social or teaching setting. Such posts-and those similar to the ones above, which might render definitive responses or best practices-tend to either a) gain a multitude of "Likes" as a form of support or solidarity (Brandtzaeg and Haugstveit 2014), or b) ignite arguments in a "commenting war," wherein the poster and the commenter fire off their opposing views, often without acknowledging what the other is saying (Vraga, Thorson, Kligler-Vilenchik, and Gee 2015). The exchange of comments may continue for a short amount of time, typically ending with no resolution; they may also extend to private conversation outside of the comment

Bernard, Cara Faith, and Matthew Rotjan. 2021. "It depends:" From narration sickness to wide awake action in music education. Action, Criticism, and Theory for Music Education 20 (1): 5383. https://doi.org/10.22176/act20.1.53 
thread, which then eliminates others from the opportunity to participate in the discussion. However, research suggests that one's online or social media activities do not transcend offline into participation or action (Breuer and Farooq 2012; Matias 2014; Cabrera, Matias, and Montoya 2017). These online platforms become social spaces-outlets-to share one's ideas, knowledge, or self-awareness (Smith 2017). Through a series of clicks (Halupka 2014), then, likes and comments become their own form of narration sickness: a perpetuation of narration that lacks both context and the possibility for follow through.

Some might define social media as its own form of action, occurring when one creates a post to spread an idea, inviting participation in the idea (Jenkins et al 2016). Of course, certain posters might trend in their topics of discussion, which reflect their values toward issues, events, or people. In some cases, a group of people noticing a pattern of posts with similar values might create a group or new page-a space where those posts share dialogue. A poster might also have an implicit understanding and following from "friends" and "followers" who understand the message of such a vague post as "YES!" "This," or a retweet/sharing of content without explanation. Of course, actions may result and attach themselves to these posts; other times, the words themselves live alone as ideas and common understandings-narration-between participants. However, Henry Jenkins and Nico Carpentier (2013) proposed a clear distinction between "participating in" and "participating through" social media; as one participates in these calls for change or queries online, they can control the ways in which they participate. One can choose the ways in which they want to participate in the conversation through lurking (following the conversation without direct participation), "Liking," abrupt stops in responding, or "unfollowing," "ghosting," or blocking the poster from participating (Abramo 2016; Bernard, Weiss, and Abeles 2018; Cayari 2021; Hine 2005; Juhasz 2008). For us as authors, these posts and declarations of one's self-awareness of existing problems become a false banking of ideas-a "blah" of words-which exist in the ether with no actionable approach for the readers. There is opportunity to engage with people while simultaneously choosing to avoid, minimally interact with, and limit conversation with those who may be "too differently different or who think too differently" in ideas (Allsup 2020, 32). In these settings, particularly online, one can say what they want, but they are not required to listen to anyone's responses or to take action beyond their words; nor can one know for sure what

Bernard, Cara Faith, and Matthew Rotjan. 2021. "It depends:" From narration sickness to wide awake action in music education. Action, Criticism, and Theory for Music Education 20 (1): 5383. https://doi.org/10.22176/act20.1.53 
action may result from such a post or discussion without further engagement with the poster or post.

Social media posts and queries may be interpreted as examples of problem posing (Freire 1970, 79). On social media, there is no direct visible link between problem posing and solving, which Freire noted must happen in dialogue and communications in which both parties engage in active listening and responding to one another. The void between problem posing and solving furthers narration sickness through a banking of ideas and potential solutions that do not necessarily require a synthesis of change-what Freire might term transformation (94)-from communication and reflection of context. Though laborers may pose questions and garner responses, the role of the thinker is reinforced by accepting a response and "solving the problem" through a prescribed action. Thinkers, too, may continue to generate thought and conversation without application. In doing so, praxis is absent, and the "blah" and "babbling" of narration sickness continues.

\section{Narration Sickness in Conferences and Professional Development}

Perhaps more apparent through its structure and setting, narration sickness manifests in conferences and in professional development opportunities. In their typical structure, conferences and professional development workshops have become spaces for one to disseminate information in bounded time (Hedden 1979, Odena 2004). Attendees sit in front of the presenter and often have little interaction with them (Rowley-Jolivet and Carter-Thomas 2005); as a result, they are left to filter the information and apply it in context themselves.

For example, we recently sat in a conference presentation about edTPA and music education. Developed by Stanford Center for Assessment, Learning, and Equity (SCALE) and Pearson Education, edTPA is a portfolio required by many states for teacher candidates to obtain initial certification (SCALE n.d.). The presenter spoke passionately about the neoliberal agendas steeped in the policies of edTPA. Despite these state mandated compliances, the presenter called for music teacher educators to fight the system in favor of more socially just evaluation and assessment. While the presenter argued that teacher candidates comply with these policies in order to enter the profession, they did not provide any examples of acts of resistance or subversion that they-or music teacher educators-might take to-as the presenter said-“fight the system." At the end of the session an attendee asked,

Bernard, Cara Faith, and Matthew Rotjan. 2021. "It depends:" From narration sickness to wide awake action in music education. Action, Criticism, and Theory for Music Education 20 (1): 5383. https://doi.org/10.22176/act20.1.53 
"What can my students and I do to engage in acts of subversion?" The presenter said, “I don't know. I can't tell you that answer because I don't know your setting. You have to think about what would work for you and respond accordingly," and moved on. Here the presenter gave a compelling argument for the ills of edTPA, yet could not name even one act of resistance that one might take in a universal teaching setting, let alone a particular one.

Conversely from the "it depends" edTPA situation above, we have sat in professional development sessions where a facilitator shared their practices around assessment. The facilitator shared "foolproof ways" to create playing rubrics, devise meaningful exit slips, and assess student performance through reflections so that all students might actively participate in self-assessment. There was no discussion of how the presenter or their institution framed assessment, or how the techniques might be modified based on teachers' setting, students, and teaching context. In this session, implicit assumptions existed: the received, or "banked" knowledge of practice might be replicated exactly in a different setting. Also implied was that attendees already knew how to adapt the session to their own situations. This session was presented as almost all action with no apparent theory, "which renders it purely technical, or worse yet neutral, work[ing] toward the instrumental training of the learner [which] will adhere too much to the banking model" (Freire and Araújo 1998, 98, italics in original). The session was in direct contrast to the edTPA session we attended, in which there was little to no guidance for taking action. In other words, there was no space to even say, "it depends," because the actions were prescriptive of how to do something. Yet, similar to the edTPA session, context was not addressed, creating an imbalance of theory with practice.

Similar to social media, sharing a foolproof teaching practice at a conference or professional development session may also contribute to narration sickness. Ideas of what to do and why to do it, perhaps with little dialogue, are presented with a separation of teacher and student-of presenter and attendee. While there is much research and practice on topics of both edTPA and assessment practices in music education that simultaneously call for change and provide some suggestions for how change might be implemented based on setting (Bernard and McBride 2020, Parkes and Powell 2015, Powell and Parkes 2019), divisions remain between thought and action. In conferences and professional development, this division may inherently occur structurally, through limitations of the design of a

Bernard, Cara Faith, and Matthew Rotjan. 2021. "It depends:" From narration sickness to wide awake action in music education. Action, Criticism, and Theory for Music Education 20 (1): 5383. https://doi.org/10.22176/act20.1.53 
session or conference itself, including time limits for presentations/workshops. Even so, given these structural limitations and in similar fashion to reposting and retweeting, ideas and practices are circulated without dialogue about context and praxis. Again, words or theory become "blah blah blah, and practice, pure activism" (Freire 1998, 30), dividing thought and actions.

\section{Narration Sickness as Grand Narrative and Slacktivism}

The examples described in the previous sections call into question where and how action occurs. Likewise, we notice that often the narrations are not personal ones generated by an individual, but rather, they are part of a grand narrative that continues to be adopted and passed along. In our observations, use of these shared narratives on social media (the posts of articles that say "This!"), in conference presentations and in professional developments (giving "it depends" answers), seems to relieve the individual burden of action by saying the action itself is the post, article, or session (Jenkins and Carpentier 2013, Jenkins 2016, Shrestova 2016). Articles may be posted and reposted, turned into professional development, shared on social media, and re-written, without ever making their way into the classroom or inviting praxis to the conversation. Although these articles may generate worthwhile conversations, we believe that music educators of all levels hide (unknowingly or knowingly) behind these narratives, simultaneously using them as a mechanism to avoid engaging in conversations around specific contexts or about how our actions might depend upon and vary in each circumstance.

When grand narratives such as the ones referenced on social media, in conferences, and in professional development sessions become shared by many with no context or follow through attached, they become bounded discussions without transformation. Further, when words only exist in a bounded and social space, not tied to an actionable strategy, narration sickness grows and opportunity for praxis lessens. The unactionable words, then, become a form of slacktivism. Henrik Christensen (2011) defined slacktivism as "political activities that have no impact on real-life political outcomes, but only serve to increase the feel-good factor of the participants" (1). This term has become synonymous with "armchair activism" (Morozov 2012), where online responses-such as Likes, comments, and sharing posts/retweeting-help an issue to gain prominence within a popular discourse without the participant ever having to leave the couch, all the while feeling good

Bernard, Cara Faith, and Matthew Rotjan. 2021. "It depends:" From narration sickness to wide awake action in music education. Action, Criticism, and Theory for Music Education 20 (1): 5383. https://doi.org/10.22176/act20.1.53 
about their "action" (Abramo 2020, Dean 2009, Vie 2014). Slacktivism or armchair activism is a prime example of how narration thrives without praxis, where inaction is disguised as action. The disguise, however, has a "limited shelf life" (Drumbl 2012, 484).

Sharing the narrative in social spaces-calling for change-allows one to declare their own self-awareness (Smith 2017). This declaration becomes an "almostbadge" of honor for being able to see and name a problem without doing something with the problem. In this sense, music educators display their ability to be "woke." We recognize the inherent problem of using such a term-one rooted in racial injustice, of "staying woke," which has gained popularity through the Black Lives Matter movement ${ }^{2}$ (Hess 2016, Sanders 2018). “To be a woke person," Aeriel Ashlee, Bianca Zamora, and Shamika Karikari (2017) suggested, "is to hold an unretractable embodied consciousness and political identity acknowledging the oppression that exists in individual and collective experiences" (90). More recently in social settings, however, calling oneself woke represents "an urge [for one] to announce his newfound self-awareness to the world. He might even want some public recognition, a social affirmation of the work he has done on himself" (Hess 2016, para 1). In other words, to be woke is to hold a sense of knowledge and thus a social capital by naming a system's existence in public settings. It is in this sharing, this self-declaration and problem posing, that narration sickness grows.

Some have argued that being "woke" might help music teachers be more aware of the "injustices that take place in our students' lives" (Palmer 2018, 23). We argue that "woke" has become a banner word to encompass more social constructs, to name social problems, inequities and awareness, and in many respects has become its own form of slacktivism in and out of music education-to talk more and do less. Recently, President Barack Obama (2019) spoke to issues of solely naming problems and being woke, particularly through social media:

Like if I tweet or hashtag [...] then, I can sit back and feel pretty good about myself. 'Cuz man, you see how woke I was? I called you out ... [pantomimes relaxing post-tweet, turning on television and changing channels]. If all you're doing is casting stones you're probably not going to get that far. (57:36)

Here, Obama hinted that one's actions may be confined to a passive action, adopting a wokeness, talking more and acting less-the self-serving type of affirmation against which Hess (2016) argued. He called for one to be in the problem. Have music educators become slacktivists by merely talking about issues in their

Bernard, Cara Faith, and Matthew Rotjan. 2021. "It depends:" From narration sickness to wide awake action in music education. Action, Criticism, and Theory for Music Education 20 (1): 5383. https://doi.org/10.22176/act20.1.53 
social media posts and conferences and not doing something in their settings, or by perpetuating best practices without attention to theory or context? Have music educators spent too much time talking about change, talking about what students need to do, instead of doing it? While we do not know the extent to which music educators may be taking action, we fear that those working in our field have become slacktivists, perpetuating an unactionable narration sickness to students and colleagues. In a sense, the ideas are merely floating.

Alfie Kohn (1999) warned that when one no longer examines nor takes action upon an idea with attention to context, the idea itself is what holds power, not the person:

There is a time to admire the grace and persuasive power of an influential idea, and there is a time to fear its hold over us. The time to worry is when the idea is so widely shared that we no longer even notice it, when it is so deeply rooted that it feels to us like plain common sense. At the point when objections are not answered anymore because they are no longer even raised, we are not in control: we do not have the idea; it has us. (3)

While one may be able to express ideas through social media, articles, and conferences, action is elusive. Declarations of naming problems, or problem posing, in social contexts may seem more important than the action. Though one critiques an idea, the larger idea-the narrative-still has a hold, leaving the discourse the same. The idea, then, becomes more central than the action itself, the roles of thinker and laborer further divided.

\section{A Wide-Awake Counter}

Maxine Greene offered a counter to wokeness and narration sickness, what she calls "wide awake." She positioned "wide awake" as an "awareness of what it is to be in the world" (Greene 1995, 35). So, to be woke, then, does not mean the same as to be wide awake, as wide awake holds a sense of being, of action associated with one's knowledge. Wide awake moves beyond the verbalism of words and narration and applies the words and ideas in contextual, actionable ways. For Greene (2005) "The ... educator must be awake, critical, open to the world. It is an honor and a responsibility to be a teacher in such dark times-and to imagine, and to act on what we imagine, what we believe ought to at last be" (80).

We identify the key words in Greene's quote to be "act on what we imagine." In other words, imagination relies on an educator's transformation (Clandinin

Bernard, Cara Faith, and Matthew Rotjan. 2021. "It depends:" From narration sickness to wide awake action in music education. Action, Criticism, and Theory for Music Education 20 (1): 5383. https://doi.org/10.22176/act20.1.53 
2009, Jorgensen 1995) -in both naming a problem and then creating ways in which to do something with the problem. Wide awakeness, then, is possible when we have a sense of what could be in our situations. Like praxis, it connects a sense of purpose and nuanced understanding of a situation with making a change, applying action to the realities of the classrooms, to "the given situation in which we act" (Freire 1985, 124).

However, it is up to the reader/poster/writer, conference attendee, or educator to act upon the imagination-words, ideas-with attention to situation and context in supple ways that work for them. Allsup (2003) reminded that "for praxis to be transformational, for human activity to ignite the slow possibility, we must understand reality as a malleable condition, neither mechanistically fixed nor solipsistically interpreted" (162). When a field suffers from narration sickness and selfserving wokeness, how might music educators (K-12, music teacher educators, and researchers) embrace the space between thought and action in malleable yet affective ways-to problem pose, reflect, and "commit [themselves] to [teaching and] learning in times like these?” (Greene 2008, 18).

\section{From Woke to Wide Awake: Actionable Examples}

Greene (1977) described the importance of attention, linking what we might identify as ideas, or words, with action:

Only the performing and especially the working self is fully interested in life and, hence, wide-awake. It lives within its acts and its attention is exclusively directed to carrying its project into effect, to executing its plan. This attention is an active, not a passive one. Passive attention is the opposite to full awareness. (121)

Passive attention, as Greene explained, can presently be seen in the act of solely naming problems and calling for change without attention to situation or context, thus engaging slacktivism and exhibiting wokeness.

In order to imagine more actionable, wide awake approaches, we highlight stories of three current, in-service music educators in different stages of their careers who attend to different facets of wide awakeness in their positions. We have engaged in ongoing professional work with these educators, consistently observing the ways in which they connect ideas to action. Having received consent from the educators-Matt being one of the three-we share their quotes from our most re-

Bernard, Cara Faith, and Matthew Rotjan. 2021. "It depends:" From narration sickness to wide awake action in music education. Action, Criticism, and Theory for Music Education 20 (1): 5383. https://doi.org/10.22176/act20.1.53 
cent conversations, which we recorded. We use their real names instead of pseudonyms at their request. These educators cannot say "it depends," as their students and specific teaching contexts depend upon their actions daily. They are required to make choices that are personal for their students' and cannot always let the grand narratives or "passive attention" overpower. We hope that situating examples in K-12 settings might provide contexts-"an interpretation of present and emergent needs" (Greene 1978, 100)-that awaken how to call for and create change in and beyond K-12 education. We hope that those in higher education might also benefit from such examples, so that they might consider what change looks like in a post-secondary setting, particularly given the ways in which action is contextualized in methods courses, as well as how research is disseminated through the interrogation of problems and potential implications.

Our three examples show a wrestling with words and ideas to action around concepts of problem-posing education, repertoire selection, and culturally responsive teaching. The teachers problem pose around ideas, reflecting and problem solving in their teaching in ways that make sense to meet the needs of their students and contexts. In these moments, they disrupt the cycle of narration sickness in spaces on social media, conferences, and professional development to engage with actionable change. Their stories exemplify how a praxial approach, combined with being wide awake when faced with challenging moments of thinking, teaching, and learning, enables teachers to take on the roles of both thinker and laborer.

\section{Matt}

Matt teaches middle school orchestra in a district that prides itself on strong performing groups. Recently, he has found frustration with the music department's course offerings, which include band, chorus, orchestra, and an exploratory music class. Matt, a veteran teacher, feels that the offerings fail to provide students with cross-curricular creative experiences that connect to their lives outside of school. Instead, courses are tied to the expectations of traditional music programs, reliant upon performing ensembles and general music. Matt is faced with a decision to overhaul the orchestra curriculum in a way that distinguishes it entirely from chorus and band or to look elsewhere for creative opportunities in the school that add to the artistic offerings.

Bernard, Cara Faith, and Matthew Rotjan. 2021. "It depends:" From narration sickness to wide awake action in music education. Action, Criticism, and Theory for Music Education 20 (1): 5383. https://doi.org/10.22176/act20.1.53 
Matt looks beyond orchestra for opportunities that connect all students with cross-curricular arts opportunities. He wonders, "What can our students create on their own with their musical and artistic knowledge?" Matt wants to create an opportunity for students to make art that reflects the world in which they live, not just one in which they play existing repertoire. He envisions students making art wherein they "explore global climate change, build instruments from recycled materials, express themselves about bullying, empathy, and any topic related to growing up in the world they live in." For guidance, Matt seeks professional development by attending his state music educators' association conference and joining two music educator Facebook groups. Matt also seeks out recent journal articles that address his concerns, including Music Educators Journal, Update: Applications of Research in Music Education, and Action, Criticism, and Theory for Music Education. He finds interest in literature regarding project-based learning, collaborative teaching, and critical pedagogy.

Matt's school has multiple after school programs dedicated to "critical thinking," in which students hone their "21st century skills, including communication, collaboration, creativity, and technology and media literacy" in different content areas. Two of the most popular clubs at his school are Robotics and Science Olympiad. To address the gap in art making in the music department, Matt endeavors to approach "critical thinking" differently than these two programs do, looking intentionally through a Freirean lens wherein students actively name the world around them (Freire 1970). He wants his students to choose a topic through discussion and decide what problems beg inquiry; together, they use this problem and decide on a topic of mutual interest based on their shared experiences as eighth grade students (Abrahams and John 2015, Abrahams 2019). Matt creates an afterschool program offering a broad artistic venue, allowing students "to understand and express their world through not just music, but also visual arts, theater, and any available technology" to create an "artistic maker space."

Matt collaborates with an art teacher to co-direct the program, giving students access to visual art materials, a computer lab, and school owned instruments. Together Matt, the art teacher, and students wrestle with the problem of growing up and going to college, jumping into the "great unknown." They create a story based not only on their anxiety about growing up, but also their wondrous excitement about it. Using unicorns and dragons as main characters, the students write a fable

Bernard, Cara Faith, and Matthew Rotjan. 2021. "It depends:" From narration sickness to wide awake action in music education. Action, Criticism, and Theory for Music Education 20 (1): 5383. https://doi.org/10.22176/act20.1.53 
and illustrate scenes, storyboarding their tale, and putting narration to music composed in GarageBand, using found sounds, instruments, and pre-recorded loops. They are encouraged to draw from their experiences in school to write a story based on a topic of mutual interest. By giving students opportunities to name their world, Matt lifts a barrier to artistic collaboration that is normally imposed on his orchestra classes. He believes that such a space will allow students to translate their perception of the problem to artistic representation and new understanding (Giroux 2011).

Matt and his art colleague develop the program further, inviting all students from the school to enroll in the club, hoping that student collective interest, artistic abilities, and creative action expand to those outside of the orchestra class. His students freely explore a concept through multiple artistic media that are not only important to their lives but also generated from their dialogue with one another. A new space is now open for learning and making connections to lived experiences through the arts (Greene 1995).

\section{Luciana}

Luciana is a K-8 general music teacher in an urban school with a large influx of refugee students in the lower elementary grades. The students-ages 5 to 8-speak little to no English, having recently arrived at the school from countries including Syria, Afghanistan, and Yemen. Luciana knows little about her new students' backgrounds but acknowledges that her regularly scheduled curriculum, lesson plans, and resources might need revisiting amidst this new student setting. She questions the relevance of her current curricular content, wondering if the traditional canon of American folk songs used in elementary school is the best fit for her students. While she recognizes the value of these folk songs in her practice, Luciana feels that they need to be "tabled for a bit because something just doesn't feel right" about, as Bowman (2007) stated, "sticking to the comparatively easier business of teaching children tis and tas, note values, and how to sing together in tune" (3).

A singleton music teacher in her school for the nine years of her career, Luciana uses social media for guidance and inspiration. She searches music educator groups on Facebook and several Twitter accounts for discussions relating to assimilation, culturally relevant pedagogy, repertoire, and curriculum. Luciana finds many posts about what teachers in similar situations do with their own students.

Bernard, Cara Faith, and Matthew Rotjan. 2021. "It depends:" From narration sickness to wide awake action in music education. Action, Criticism, and Theory for Music Education 20 (1): 5383. https://doi.org/10.22176/act20.1.53 
One teacher remarked, "Several of my students this year are from China, so I have decided to teach several Chinese folk songs." Another teacher replied, "Just because your students are from China doesn't mean you should choose Chinese folk music for them to enter your classroom musically." A firing of comments ensued from a multitude of teachers, arguing various perspectives.

Luciana considers her students and what might happen in class if she tries to introduce folk songs of Syria, Afghanistan, and Yemen. She questions, "why would I do this?" and "is it helpful to them, and can I do this music justice?" She is confronted with the tension of including her students through content. Luciana considers the ways in which she can think through curriculum to encourage the participation of her students so that they might begin to feel comfortable in class without "simplifying" their identities (Ocádiz Velázquez 2020). In other words, Luciana is concerned with "making music that recognize[s] the distinctiveness of each of [her] students, newly arrived and previously known" (19).

The social media exchange prompts Luciana to list possible valuable, accessible experiences for the students in her music class: "I'm not completely sure what I should be teaching at this point, but one thing I know is that we're not going to sing songs about wagon wheels and wandering buttons with these newcomers...they traveled across the world and we're singing about moving buttons and wheels? No way." Luciana references the folk songs "Old Brass Wagon" and "Button You Must Wander," two songs often used in elementary music curricula. She brings a critical eye to these seemingly innocent songs (Hess 2019, Howard 2020) for a classroom full of newcomers, aware that these songs require a certain knowledge of history and context unknown to her new students.

Luciana is cautiously aware that the contents of the aforementioned songs connote an idea of a journey, one steeped in America's history of exploration and expansion. While some teachers might consider using these songs to learn more about their students, asking "tell me about your journey," or "where is your wagon or button going?" Luciana recognizes that many of her students have been on an arduous journey, leaving their places of origin and coming to a new location. She does not feel that highlighting this part of her students' backgrounds is a worthy entry point to get to know them. Additionally, the stories told in these folk songs may connote a colonial undertone (Bradley 2009), or, as Luciana says, "moving into someone else's space and taking control."

Bernard, Cara Faith, and Matthew Rotjan. 2021. "It depends:" From narration sickness to wide awake action in music education. Action, Criticism, and Theory for Music Education 20 (1): 5383. https://doi.org/10.22176/act20.1.53 
Instead, Luciana demonstrates a moment of awakening as she begins to develop strategies and repertoire to build students' confidence and socio-emotional well-being as they settle into a new school, community, and language. She incorporates "less colonial and more neutral" repertoire that provides students the opportunity to speak, chant, or sing their names, and identify colors, move, and dance. Although at one time she would have judged herself for "choosing songs like 'John Jacob Jingle Heimer Schmidt' that don't have much educational or musical meat to it," Luciana describes feeling ethically better in her choice to not essentialize students' real or perceived identities/places of origin that could be gleaned from the music. She wants to engage in music with her students to form relationships and "foster a comfortable and fun classroom environment and get to know them casually before opening a conversation about a potentially traumatic journey and personal ordeal." As students become comfortable, Luciana sees an opportunity to learn more about their experiences and backgrounds without overlooking or overemphasizing them (Karlsen 2014).

Singing and chanting through the new repertoire-songs such as "Wheels on the Bus," "Head, Shoulders, Knees, and Toes," and a host of "Hello" or name game songs-creates a positive alternative for Luciana and her students. She notices her students singing out more, wanting to sing alone or embrace the small 4-beat moments of improvisation in a song. Deviating from the curriculum, Luciana reflects, allows the students a more neutral yet satisfying musical experience that simultaneously allows them to reach curricular musical goals of "reading iconic and musical notation, and singing alone in tune, while growing confidently together as a class."

While Luciana's colleagues on social media might argue that singing songs from students' cultural backgrounds is relevant-practicing culturally relevant teaching-Luciana acknowledges the importance of time needed for students to adjust to and feel comfortable in a new situation. Based on students' comfort and readiness levels, she makes judgements about when to incorporate larger social issues or how to introduce and contextualize curricular content (repertoire). In a sense, then, Luciana is "breaking through" her initial discomfort (Ocádiz Velázquez 2020) arising from straying from the curricular musical tradition of American folk songs and notation in an aim to respond to who her students are at that moment (Lind and McKoy 2016). She displays a sense of wide awakeness through her reflection and making deliberate choices regarding repertoire and curriculum. She is

Bernard, Cara Faith, and Matthew Rotjan. 2021. "It depends:" From narration sickness to wide awake action in music education. Action, Criticism, and Theory for Music Education 20 (1): 5383. https://doi.org/10.22176/act20.1.53 
able to consider and restructure her curriculum to be sensitive to her students in a way that does not force a standard curriculum or insensitive conversation around a journey. More importantly, Luciana's changes allowed for a greater sense of comfort and trust in the classroom. Luciana knows she is at the beginning of this change-what we deem as wide awakeness, describing that while she is not "done with this work yet, this is a big start." However, she is gaining agency in her decisions, "which will let me go deeper with other music and activities, but to really build relationships with the students."

\section{$\operatorname{Rex}$}

Second year teacher Rex teaches preK-5th grade general music at a rural, yet culturally and economically diverse, elementary school. As one of two male teachers in his school, he hears and experiences stereotyped gender norms and bias from his colleagues on a daily basis. As a result, Rex is extremely aware of the ways in which heteronormative gender is constructed in teaching and learning in schools, particularly at the elementary level. This awareness is heightened when Rex attends a series of conference presentations at which the presenter teaches some elementary singing games. During the session, the participants pair up by gender to learn some Appalachian play parties. They sing a variety of folk songs, which as Rex describes, position men as the valiant hero and women as the "more pretty, delicate, demure person who has very specific roles as a female." Rex notices in the session that the presenter's focus is on the transmission of the song and game so that students can bring music, movement, and play together. He is surprised by the lack of discussion about heteronormative gender roles in the songs. Rex leaves the session wondering, "We learned and read a lot about gender in college. Would these songs and everything that accompanies them be appropriate for my students?"

Additionally, Rex knows he cannot talk about gender norms with his school colleagues because eliminating, reducing, and discussing gender bias is less important to them than covering the prescribed curriculum or the upcoming standardized tests. He feels somewhat alienated at school because a discussion of gender seems an unapproachable professional topic. In response to the session and his professional environment, Rex chooses to address these issues in subtle ways in his classroom.

Bernard, Cara Faith, and Matthew Rotjan. 2021. "It depends:" From narration sickness to wide awake action in music education. Action, Criticism, and Theory for Music Education 20 (1): 5383. https://doi.org/10.22176/act20.1.53 
Rex applies his concerns from the professional development session for his classroom and decides to bring his awareness of gender bias to his pedagogy through careful use of language. Choosing to start with the song "Baby Shark" 3 with kindergartners, Rex asks the students about the characters in the story: "I said to them, 'this story has a mama shark, a daddy shark, and a baby shark; does every family have a mom and a dad?" One child responds, "my mom died; it's just me and dad." Rex uses this opportunity to acknowledge that families can look different. Also, Rex draws attention to the movements the students make while singing each family character in the song; they instinctively make larger hand motions for the daddy shark, smaller hand motions for the mommy shark, and very small motions for the baby. He says, "I notice the daddy shark is bigger in size than the mommy shark. Are men always bigger than women?" Upon the students responding, "No," Rex reminds them that "people are of all shapes and sizes, just because they're mommy or daddy or boy or girl doesn't mean they're bigger or smaller." For Rex, incorporating what the students bring in from home or popular culture is a small yet effective way to address these gender biases.

Rex also attends to gender roles and norms using games and theater in the classroom. When studying Scheherazade, a story Rex uses to help students identify different instruments of the orchestra and how they might evoke different moods, he has students act out the roles. He wants students to feel comfortable playing any part they choose, regardless of gender norms. Rex opens up parts in the play to all of his students: "Anyone-and I use that word very specifically-is welcome to play any part," he says. "We're here to make believe, and that means anyone is free to play any part," he says to his students. Rex strives to create a classroom conducive to the role rather than the gender norm associated with it:

I never force anyone to break a gender barrier; it's never a requirement. There are some giggles or resistance at first, but I quickly pace things to address the issues and we move on, and they don't realize that we're all moving on. It's not a big deal, it's a small change.

Like Luciana, Rex is sensitive-wide awake-to student needs. Allowing his students to play any part in the stories and music, Rex attempts to create an inviting space for students to explore characters of interest without limiting their gender roles. He chooses to bring change to his teaching space rather than instigating a school-wide movement. For example, because in Rex's experience with his work colleagues, he felt that raising LGBTQIA+ issues, based upon what he had read and

Bernard, Cara Faith, and Matthew Rotjan. 2021. "It depends:" From narration sickness to wide awake action in music education. Action, Criticism, and Theory for Music Education 20 (1): 5383. https://doi.org/10.22176/act20.1.53 
studied, "might lead colleagues to respond defensively or ask, 'What should we do about it?" Instead of taking a narration sickness approach for a school-wide initiative, responding with only hypotheticals, Rex subversively adds support for and around gender issues into his pedagogy in an age-appropriate way for his students. He might now enter those conversations with examples from his classroom and sharing about his students' experiences.

\section{A Wide-Awake Call to Action}

Matt, Luciana, and Rex exemplify wide-awake definitions of action and demonstrate a countering of narration sickness. "Wide awakeness has a concreteness," Greene wrote $(1977,121)$; it is not abstract. In their wide awakeness, Matt, Luciana, and Rex enact decisive, concrete actions; the changes they make result from thoughtful actions based on informed experiences from their teaching situations. They have allowed for words and calls for change to affect them; but more importantly, they have used these words as impetus to take action rather than wrestling with responses of "it depends." They answered the calls for change heard at conferences, at professional development sessions, and from their own reading, with action.

The three teachers embed larger ideas into their practice in an effort to make change, acting in the best interest of and with their students. Matt applies tenets of critical pedagogy both in and beyond the orchestra setting; Luciana begins to dismantle her traditional curriculum in search of more culturally relevant practices with her newcomer students; and Rex explores gender in the music classroom. The choices the three teachers make "provoke wide awakeness" in their teaching and reflecting on their own contexts (Greene 1977, 123) as they pose and solve problems. Elementary teacher Rex mentions the importance of a small change. Small changes may begin to quiet the narration sickness and dismantle the grand gestures of discourse. Narration will often raise the questions, "what" and "why" to change, yet the answer of "how" may be hidden in the bridge between the narration and the actions of teaching, researching, and learning that can affect change. Recalling Freire (1970) and Marx (1846), praxis brings the narration-the "what"together with "how" to enact. We argue that the space where the "working self" (Greene 1977), or worker, meets the narrator dismantles the duality of the thinker and laborer; it is a space for actionable, context-informed change.

Bernard, Cara Faith, and Matthew Rotjan. 2021. "It depends:" From narration sickness to wide awake action in music education. Action, Criticism, and Theory for Music Education 20 (1): 5383. https://doi.org/10.22176/act20.1.53 
Through a process of reflection, our exemplars respond with thoughtful actions relevant to their individual teaching situations. In their actions, they embrace praxis over narration sickness, and highlight a difference between being wide awake, actionable and reactive, and merely responding with nervous action (Goodson 2009). The teachers demonstrate what it means to synthesize their roles as praxial educators, dismissing the separate roles of thinker and laborer and embracing that of thinker-laborer, in similar ways to Freire's (1970) teacher-student and student-teacher. In these moments, Matt, Luciana, and Rex have control-actionover the idea (Kohn 1999).

No narration is immune to sickness. We acknowledge that even this paper might add to the "blah" or grand narrative phenomena; we are aware of the irony of our positionalities in this framework. Yet, the writing of this paper itself has allowed us to engage in fruitful conversation about calls for change, discussion of "malleable" (Allsup 2003) examples, and potential implementation as thinker-laborers. We engaged in continually meaningful problem posing and solving, taking control of (grand narrative) ideas while sharing examples from our classrooms, our colleagues, and scholarship. We see our participation in research (including writing and presenting), teaching, and learning both in person and on social media strengthened by praxis.

\section{Thinking and Working Together, Praxially}

This article is an invitation for music educators of all levels, settings, and backgrounds to become wide awake to the problems of narration without contextual action, in order to lessen the divide between thinking and doing. Similar to the opening quotes of this paper, we recognize that, indeed, calls for change truly do depend on the situation. Paying little attention to situational factors such as setting, school culture, resources, and student demographics can lend to great variability and nuance, which may thus reiterate more narration and "characteristic language of intellectuals [the traditional thinker]-reflexive, critical, and situationfree," (Greene 1978, 97) and lessen the opportunities for action. We encourage music educators of all levels and backgrounds to embrace their own "it depends," so that when faced with ideas and challenges, they can act on their situations-as have Matt, Luciana, and Rex-instead of adopting a grand narrative, floating idea, or nervous action.

Bernard, Cara Faith, and Matthew Rotjan. 2021. "It depends:" From narration sickness to wide awake action in music education. Action, Criticism, and Theory for Music Education 20 (1): 5383. https://doi.org/10.22176/act20.1.53 
We imagine space through social media, professional development, and conferences for our exemplars to learn and discuss the ways in which they might practically implement changes in their teaching and curriculum. Examples of student work and stories, classroom videos, and scholarly literature might be reviewed and discussed with pertinent attention to situation. Music educators might consider "why" they are posting something in a reflective manner; asking if they are contributing to a grand narrative or helping the cause of problem posing/solving by sharing a contextual solution to a problem, by raising an important question about a situation or theoretical idea, or by sharing a frustration with applying an idea. Implications for research might guide readers to problem pose, reflect, and act upon their thoughts (Greene 1995).

We propose that dialogue and interplay of ideas and problems be discussed openly at conferences so that music educators may move from being slacktivists to being active educators and engage in the messiness of the conversations of "situation." While presentation/workshop time limits and other structures may constrain conferences and professional development sessions, small changes might be addressed in order to avoid recycling grand narratives. If conferences had spaces for both narration and reflective dialogue, such that music educators sat around a meeting table as in a seminar, or gathered as a team within a classroom or school; if professional development was for all stakeholders, at all levels, contributing to spaces that allow for actionable dialogue and perspective to converge and flourish with action; and if social media participants embraced more situation and context to their posts captioned, "This," to echo the positive collaborations already occurring on social media, the problems of thinking, teaching, learning, and researching may be more collaborative, reducing the gap between thinker and laborer, and woke slacktivist and the wide awake.

Such small changes may challenge the notion of inaction as action and move toward embracing and implementing context- and imagination-based change (Freire 1970, Greene 2005). When music educators-in-service teachers, teacher educators, and researchers-begin to make shifts in the spaces for learning as well as the ways in which they teach, learn, and engage professionally and socially, narration becomes more of an action-based conversation than merely "casting stones," as they embrace a wide-awake approach to music teaching and learning.

Bernard, Cara Faith, and Matthew Rotjan. 2021. "It depends:" From narration sickness to wide awake action in music education. Action, Criticism, and Theory for Music Education 20 (1): 5383. https://doi.org/10.22176/act20.1.53 


\section{About the Authors}

Cara Faith Bernard is Assistant Clinical Professor of Music Education at the University of Connecticut in the Neag School of Education, where she teaches courses in choral and elementary methods, curriculum, and supervises student teaching. Cara serves on the editorial committees of Music Educators Journal, Arts Education Policy Review, and Visions of Research in Music Education. She is co-author of the book Navigating Teacher Evaluation: A Guide for Music Teachers, published by Oxford University Press.

Matthew Rotjan teaches music in the Scarsdale Public Schools (NY), where he teaches orchestra classes at Scarsdale Middle School. Dr. Rotjan has been on the artistic staff of the InterSchool Orchestras of New York and Rockland Youth Orchestra (NY) and serves on the editorial committee of American String Teacher Journal. An innovative educator and music teacher educator, he is frequently sought out for professional development, leading sessions with educators, administrators, and students and for writing curriculum. Matthew's vignette represents work from a previous school district.

\section{References}

Abrahams, Frank. 2005. Transforming classroom music instruction with ideas from critical pedagogy. Music Educators Journal 92 (1): 62-7.

Abrahams, Frank. 2019. A case for integrative assessment from a Freirean perspective. In The Oxford handbook of philosophical and qualitative assessment in music education, edited by David J. Elliott, Marissa Silverman, and Gary E. McPherson, 257. New York: Oxford University Press.

Abrahams, Frank, and Ryan John. 2015. Planning instruction in music: Writing objectives, assessments, and lesson plans to engage artistic processes. Chicago: GIA.

Abramo, Joseph Michael. 2016. \#MarchOnRome: Of alterity, social media, and marching bands. Action, Criticism, and Theory for Music Education 15 (3): $113-31$.

Abramo, Joseph Michael. 2020. The "Social Justice Plot" in learning, consuming, and (re)creating music on social media. Journal of Popular Music Education 4 (2): 193-210.

Allsup, Randall Everett. 2003. Praxis and the possible: Thoughts on the writings of Maxine Greene and Paulo Freire. Philosophy of Music Education Review 11 (2): $157-69$.

Bernard, Cara Faith, and Matthew Rotjan. 2021. "It depends:" From narration sickness to wide awake action in music education. Action, Criticism, and Theory for Music Education 20 (1): 5383. https://doi.org/10.22176/act20.1.53 
Allsup, Randall Everett. 2020. On the perils of wakening others. In Humane music education for the common good, by Iris M. Yob and Estelle Jorgensen, 29-39. Bloomington: Indiana University Press.

Ashlee, Aeriel A., Bianca Zamora, and Shamika N. Karikari. 2017. We are woke: A collaborative critical autoethnography of three "Womxn" of color graduate students in higher education. International Journal of Multicultural Education 19 (1): 89-104.

Bernard, Cara Faith, Lindsay Weiss, and Harold F. Abeles. 2018. Space to share: Interactions among music teachers in an online community of practice. Bulletin of the Council for Research in Music Education 215: 75-94.

Bernard, Cara Faith, and Nicholas McBride. 2020. "Ready for primetime:" EdTPA, preservice music educators, and the hyperreality of teaching. Visions of Research in Music Education, 35. http://www-usr.rider.edu/ vrme/v35n1/visions/Bernard\%20and\%2oMcBride_Hyperreality\%2oManuscript.pdf

Bowman, Wayne D. 2007. Who's asking? (Who's answering?) Theorizing social justice in music education. Action, Criticism, and Theory for Music Education 6 (4): 1-20.

Boyd, Danah, Matt Golder, and Gilad Lotan. 2010. Tweet, tweet, retweet: Conversational aspects of retweeting on twitter. In 2010 43rd Hawaii International Conference on System Sciences, 1-10. IEEE.

Bradley, Deborah. 2009. Global songs, global citizens? The world constructed in world music choral publications. In Exploring social justice: How music education might matter, edited by Elizabeth Gould, June Countryman, Charlene Morton, and Leslie Stewart Rose, 105-119. Canadian Music Educators' Association.

Brandtzaeg, Petter Bae, and Ida Maria Haugstveit. 2014. Facebook likes: A study of liking practices for humanitarian causes. International Journal of Web Based Communities 10(3): 258-79.

Breuer, Anita, and Bilal Farooq. 2012. Online political participation: Slacktivism or efficiency increased activism? Evidence from the Brazilian Ficha Limpa campaign (May 1). https://papers.ssrn.com/sol3/papers.cfm?abstract_id= 2179035

Cabrera, Nolan L., Cheryl E. Matias, and Roberto Montoya. 2017. Activism or slacktivism? The potential and pitfalls of social media in contemporary student activism. Journal of Diversity in Higher Education 10 (4): 400-415.

Bernard, Cara Faith, and Matthew Rotjan. 2021. "It depends:" From narration sickness to wide awake action in music education. Action, Criticism, and Theory for Music Education 20 (1): 5383. https://doi.org/10.22176/act20.1.53 
Cayari, Christopher. (2021). Collaborative video logs: Virtual communities of practice and aliveness in the music classroom. In The Routledge handbook to sociology of music education, edited by Ruth Wright, Panos A. Kanellopoulos, Geir Johansen, and Patrick Schmidt, 443-55. London: Routledge.

Christensen, Henrik Serup. 2011. Political activities on the internet: Slacktivism or political participation by another means? First Monday 16 (2): 1-10.

Clandinin, D. Jean. 2009. Troubling certainty: Narrative possibilities for music education. In Narrative inquiry in music education, edited by Margaret S. Barrett and Sandra L. Stauffer, 201-209. New York: Springer.

Class, Jessenia N., and Robert Miranda. 2019. Writing as activism. The Harvard Crimson. https://www.thecrimson.com/column/opining-from-the-chair/article/2019/10/17/class-miranda-writing-activism/

Dean, Jodi. 2009. Democracy and other neoliberal fantasies: Communicative capitalism and left politics. Durham: Duke University Press.

Drumbl, Mark A. 2012. Child soldiers and clicktivism: Justice, myths, and prevention. Human Rights Practice 4(3): 481-85.

Elliott, David J., Marissa Silverman, and Gary E. McPherson, 2019. Introduction, aims, and overview. In The Oxford handbook of philosophical and qualitative assessment in music education, edited by David J. Elliott, Marissa Silverman, and Gary E. McPherson, 3-26. New York: Oxford University Press.

Freire, Paulo. 1970. Pedagogy of the oppressed. New York: Continuum.

Freire, Paulo. 1985. The politics of education: Culture, power, and education. Westport, CT: Bergin and Garvey.

Freire, Paulo, 1998. Pedagogy of freedom: Ethics, democracy and civic courage. Lanham, MD: Rowman \& Littlefield.

Freire, Paulo, and Ana Maria Araújo. 1998. Pedagogy of the heart. London: Bloomsbury Publishing USA.

Giroux, Henry A. 1988. Teachers as intellectuals: Toward a critical pedagogy of learning. Westport, CT: Greenwood Publishing Group.

Giroux, Henry. 2011. On critical pedagogy. New York: Continuum.

Goodson, Patricia. 2009. Theory in health promotion research and practice: Thinking outside the box. Boston: Jones \& Bartlett Publishers.

Bernard, Cara Faith, and Matthew Rotjan. 2021. "It depends:" From narration sickness to wide awake action in music education. Action, Criticism, and Theory for Music Education 20 (1): 5383. https://doi.org/10.22176/act20.1.53 
Greene, Maxine. 1977. Toward wide-awakeness: An argument for the arts and humanities in education. Teachers College Record 79 (1), 119-25.

Greene, Maxine. 1978. Landscapes of learning. New York: Teachers College Press.

Greene, Maxine. 1995. Releasing the imagination: Essays on education, the arts, and social change. San Francisco: Jossey-Bass.

Greene, Maxine. 2005. Teaching in a moment of crisis: The spaces of imagination. The New Educator 1: 77-80.

Greene, Maxine. 2008. Commentary: Education and the arts: The windows of imagination. Learning Landscapes 2 (1): 17-21.

Halupka, Max. 2014. Clicktivism: A systematic heuristic. Policy \& Internet 6 (2): 115-32.

Hedden, Steven K. 1979. Dissemination of music education research: Are researchers the problem? Bulletin of the Council for Research in Music Education 59: $35^{-9}$.

Hess, Amanda. 2016. Earning the "woke" badge. New York Times (April 19). https://www.nytimes.com/2016/04/24/magazine/earning-the-wokebadge.html

Hess, Juliet. 2017. Critiquing the critical: The casualties and paradoxes of critical pedagogy in music education. Philosophy of Music Education Review 25 (2): 171-91.

Hess, Juliet. 2019. Music education for social change: Constructing an activist music education. London: Routledge.

Hine, Christine. 2005. Virtual methods: Issues in social research on the Internet. London: Berg.

Howard, Karen. 2020. Equity in music education: Cultural appropriation versus cultural appreciation-understanding the difference. Music Educators Journal 106 (3): 68-70.

Jenkins, Henry. 2016. Youth Voice, Media, and Political Engagement: Introducing the Core Concepts. In By any media necessary: The new youth activism, Vol. 3, edited by Henry Jenkins, Sangita Shresthova, Liana Gamber-Thompson, Neta Kligler-Vilenchik, and Arely M. Zimmerman, 1-60. New York: NYU Press.

Jenkins, Henry, and Nico Carpentier. 2013. Theorizing participatory intensities: A conversation about participation and politics. Convergence 19 (3): 265-86.

Bernard, Cara Faith, and Matthew Rotjan. 2021. "It depends:" From narration sickness to wide awake action in music education. Action, Criticism, and Theory for Music Education 20 (1): 5383. https://doi.org/10.22176/act20.1.53 
Jenkins, Henry, Sangita Shresthova, Liana Gamber-Thompson, Neta KliglerVilenchik, and Arely Zimmerman. 2016. By any media necessary: The new youth activism, Vol. 3. New York: NYU Press.

Jorgensen, Estelle R. 1995. Music education as community. Journal of Aesthetic Education 29 (3): 71-84.

Juhasz, Alexandra. 2008. Why not (to) teach on YouTube. In Video vortex reader: Responses to YouTube, edited by Geert Lovink and Sabine Niederer, 133-40. Amsterdam, NL: Institute for Network Cultures.

Karlsen, Sidsel. 2014. Exploring democracy: Nordic music teachers' approaches to the development of immigrant students' musical agency. International Journal of Music Education 32 (4): 422-36. https://doi.org/10.1177/02557614135 15806

Kohn, Alfie. 1999. Punished by rewards: The trouble with gold stars, incentive plans, A's, praise, and other bribes. Boston: Houghton Mifflin Harcourt.

Ladson-Billings, Gloria. 2014. Culturally relevant pedagogy 2.0: Aka the remix. Harvard Educational Review 84 (1): 74-84.

Lind, Vicki R., and Constance McKoy. 2016. Culturally responsive teaching in music education: From understanding to application. London: Routledge.

Marx, Karl. 1846. The German ideology: Part I. In The Marx-Engels reader, $2^{\text {nd }}$ edition, edited by Robert C. Tucker. New York: W.W. Norton and Company.

Matias, Cheryl E. 2014. White skin, Black friend: A Fanonian application to theorize racial fetish in teacher education. Educational Philosophy and Theory 48 (3): $221-36$.

Morozov, Evgeny. 2012. The net delusion: The dark side of internet freedom. Public Affairs.

Obama, Barack. 2019. President Obama in conversation with Yara Shahidi and Obama Foundation Program Participants. (October 30). https:// www.youtube.com/watch?v=Ioz96L5xASk on January 25, 2020.

Ocádiz Velázquez, Gabriela. 2020. Music Education in a Liquid Social World: The Nuances of Teaching with Students of Immigrant and Refugee Backgrounds. Electronic Thesis and Dissertation Repository. https://ir.lib.uwo.ca/ etd/6824

Odena, Oscar. 2004. Some considerations on research dissemination with particular reference to the audience and the authorship of papers. Music Education Research 6 (1): 101-10.

Bernard, Cara Faith, and Matthew Rotjan. 2021. "It depends:" From narration sickness to wide awake action in music education. Action, Criticism, and Theory for Music Education 20 (1): 5383. https://doi.org/10.22176/act20.1.53 
Palmer, Elizabeth S. 2018. Literature review of social justice in music education: Acknowledging oppression and privilege. Update: Applications of Research in Music Education 36(2): 22-31.

Parkes, Kelly A., and Sean R. Powell. 2015. Is the edTPA the right choice for evaluating teacher readiness?." Arts Education Policy Review 116(2): 103-13.

Powell, Sean Robert, and Kelly A. Parkes. 2019. Teacher evaluation and performativity: The edTPA as a fabrication. Arts Education Policy Review 121 (4): 1-10.

Ravn, Ib, and Steen Elsborg. 2011. Facilitating learning at conferences. International Journal of Learning and Change 5 (1): 84-98.

Rowley-Jolivet, Elizabeth, and Shirley Carter-Thomas. 2005. The rhetoric of conference presentation introductions: Context, argument and interaction. International Journal of Applied Linguistics 15 (1): 45-70.

Sanders, Sam. 2018, December 30. Opinion: It's time to put "woke" to sleep. National Public Radio. https://www.npr.org/2018/12/30/680899262/opinionits-time-to-put-woke-to-sleep

Schmidt, Patrick. 2005. Music education as transformative practice: Creating new frameworks for learning music through a Freirean perspective. Visions of Research in Music education 6 (1): 1-14.

Shin, Ji Hae. 2018. Using interactions among in-service music teachers in a graduate programme for teacher support. Music Education Research 20 (1): 11425 .

Shresthova, Sangita. 2016. "Watch 30 Minute Video on Internet, Become Social Activist"? Kony 2012, Invisible Children, and the Paradoxes of Participatory Politics. In By any media necessary: The new youth activism, Vol. 3, edited by Henry Jenkins, Sangita Shresthova, Liana Gamber-Thompson, Neta Kligler- Vilenchik, and Arely M. Zimmerman, 61-101. New York: NYU Press.

Smith, Gareth Dylan, Mike Dines, and Tom Parkinson. 2017. Punk pedagogies: Music, culture and learning. London: Routledge.

Smith, Trevor Garrison. 2017. Politicizing digital space: Theory, the Internet, and renewing democracy. London: University of Westminster Press.

Souto-Manning, Mariana. 2019. Toward praxically-just transformations: Interrupting racism in teacher education. Journal of Education for Teaching 45 (1): 97-113.

Stanford Center for Assessment, Learning, and Equity. n.d. edTPA. https://scale.stanford.edu/teaching/edtpa

Bernard, Cara Faith, and Matthew Rotjan. 2021. "It depends:" From narration sickness to wide awake action in music education. Action, Criticism, and Theory for Music Education 20 (1): 5383. https://doi.org/10.22176/act20.1.53 
Talbot, Brent C., and Hakim Mohandas Amani Williams. 2019. Critically assessing forms of resistance in music education. In The Oxford handbook of philosophical and qualitative assessment in music education, edited by David J. Elliott, Marissa Silverman, and Gary E. McPherson, 83-100. New York: Oxford University Press.

Vie, Stephanie. 2014. In defense of "slacktivism": The Human Rights Campaign Facebook logo as digital activism. First Monday 19 (4). https://firstmonday. org/article/view/4961/3868

Vraga, Emily K., Kjerstin Thorson, Neta Kligler-Vilenchik, and Emily Gee. 2015. How individual sensitivities to disagreement shape youth political expression on Facebook. Computers in Human Behavior 45: 281-89.

Waldron, Janice. 2013. User-generated content, YouTube and participatory culture on the Web: Music learning and teaching in two contrasting online communities. Music Education Research 15 (3): 257-74.

Waldron, Janice, Stephanie Horsely, and Kari Veblen, eds. 2020. The Oxford handbook of social media and music learning. New York: Oxford University Press.

\section{Notes}

${ }^{1}$ In the original quote, Bowman (2007) speaks of social justice and socially just practices. We argue that, 13 years later, one might replace "social justice" with any concept or idea and Bowman's intentions still apply. Doing the work of social justice, cultural relevance, inclusion, etc. is not about stringing together a prescribed set of actions. Rather, it is something far deeper, which is why it must be actionable, and tied to theory, reflection, and context.

2 While the term "woke" has been used in more mainstream ways, we do not mean to use it in a way that dilutes its original meaning and roots in the Black Lives Matter movement, particularly as two teacher-researchers who identify as white.

3 See https://www.youtube.com/watch?v=XqZsoesa5.5w for reference.

Bernard, Cara Faith, and Matthew Rotjan. 2021. "It depends:" From narration sickness to wide awake action in music education. Action, Criticism, and Theory for Music Education 20 (1): 5383. https://doi.org/10.22176/act20.1.53 